This item was submitted to Loughborough's Research Repository by the author.

Items in Figshare are protected by copyright, with all rights reserved, unless otherwise indicated.

\title{
In pursuit of equity and inclusion: Populism, politics and the future of educational research in physical education, health and sport
}

PLEASE CITE THE PUBLISHED VERSION

http://dx.doi.org/10.1080/13573322.2017.1307176

\section{PUBLISHER}

(c) Taylor \& Francis

\section{VERSION}

AM (Accepted Manuscript)

\section{PUBLISHER STATEMENT}

This work is made available according to the conditions of the Creative Commons Attribution-NonCommercialNoDerivatives 4.0 International (CC BY-NC-ND 4.0) licence. Full details of this licence are available at: https://creativecommons.org/licenses/by-nc-nd/4.0/

\section{LICENCE}

CC BY-NC-ND 4.0

\section{REPOSITORY RECORD}

Evans, John, and Brian Davies. 2019. "In Pursuit of Equity and Inclusion: Populism, Politics and the Future of Educational Research in Physical Education, Health and Sport”. figshare. https://hdl.handle.net/2134/24662. 


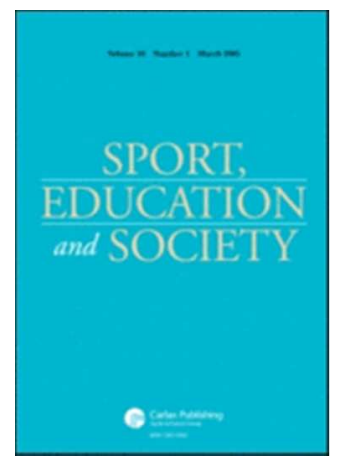

In Pursuit of Equity and Inclusion: Populism, Politics and the Future of Educational Research in Physical Education, Health and Sport

\begin{tabular}{|r|l|}
\hline Journal: & Sport, Education and Society \\
\hline Manuscript ID & CSES-2017-0044.R2 \\
\hline Manuscript Type: & Other \\
\hline Keywords: & New Right, Populism, Equality, Physical Education, Health, Sport, Research \\
\hline \multicolumn{2}{|}{} \\
\hline
\end{tabular}

\section{SCHOLARONE"}

Manuscripts 
In Pursuit of Equity and Inclusion: Populism, Politics and the Future of Educational Research in Physical Education, Health and Sport

\section{John Evans and Brian Davies}

\section{Loughborough University and Cardiff University}

$\underline{\text { John.evans@1boro.ac.uk and wbdavies@,ntlworld.com }}$ 


\begin{abstract}
Globalization and its ideological bedfellow neoliberalism have demonstrably failed to deliver on many of their promises; not least of providing greater social mobility and more educational and economic opportunities, especially to the most 'disadvantaged'. The rise of new Right, populist politics across the globe is one expression of this failure. The extent to which education policy and associated research in education, physical education (PE), health, and sport share in failure to address the interests of those disillusioned with mainstream Governments and politicians is moot, and yet to be adequately explored. As means of promoting some further reflection on this matter this paper argues that although the achievements of Physical Education, health and sport (PEHS) research communities in addressing equality and inclusion issues are many, varied, and to be applauded, they are incomplete and have come at a cost. The reasons for this lie both outwith and inside our professional practices: They refer to disturbing systemic pressures, born of neo liberalism and its manufactured austerities, threatening the wellbeing of those very disciplines and research communities that are likely to be asking searching, sometimes difficult, questions of extant social hierarchies, and to limitations within the theoretical leanings of PEHS research communities respectively.

Our analyses suggest that if research is to be seen as credible means of addressing current socio-economic change including the worst excesses of new Right populism and its effects on equity and inclusion in Physical Education, health and sport in schools and society, then it will be because its practices are grounded in research expertise and theoretical bodies of knowledge that are finely attuned both to structural inequalities and the cultural interests of its target communities.
\end{abstract}

Key Words: New Right, Populism, Equality, Physical Education, Health, Sport, Research 
Turning and turning in the widening gyre

The falcon cannot hear the falconer

Things fall apart; the centre cannot hold

Mere anarchy is loosed upon the world

The blood-dimmed tide is loosed, and everywhere

The ceremony of innocence is drowned

The best lack all conviction, while the worst

Are full of passionate intensity

(Yeats, 1919)

\section{Introduction: Whither Equality and Equity in New Right Populism?}

Like many others, Bellow (2014) claims that Liberal-Democracy is no friend of equality, globalization and its ideological bedfellow neoliberalism having demonstrably failed to deliver on many of their promises; not least of providing greater social mobility and more educational and economic opportunities, especially to the most 'disadvantaged'. The rise of populist politics in Europe, the USA, Australasia, North Africa and the Middle East, is deemed one expression of this failure (Mishra, 2016). Those 'left behind' or 'forced out' of wealth accumulation enjoyed by an increasingly remote, privileged few register their dissatisfaction, either through the ballot box, or on the streets, with political regimes that have patently failed to address income inequalities and satisfy basic human needs for security, decent homes, good education and health care. Unsurprisingly, resentment and its deeper, more destructive companion 'ressentiment' are endemic, globally (Mishra, 2016) (1).

It seems pretty evident that we are amidst a maelstrom of socio-economic and political change presaging, some say, a paradigm shift in politics, perhaps even the emergence of a new realpolitik in the UK, across Europe and the USA. Change is afoot and uncertainty prevails. Take your pick and insert the names of your own country's new Right populist advocates, each it seems, in constant state of agitated, twittering pique, claiming to be harbingers of brave new worlds. Yeats' (1919) majestic, post First World War poetic 
observations seem particularly redolent, poignant and disturbingly contemporary, 'mere anarchy seems loosed upon the world...the best lack all conviction, while the worst... are full of passionate intensity'.

The extent to which education policy and associated research in education, the sociology of physical education, health, sport and critical pedagogy share in failure to address the interests and needs of those disillusioned with mainstream Governments and politicians is moot, and yet to be adequately explored. Has recent turbulence yet touched the practices and politics of academia and its communities of educational practice and research? Are their practitioners, engaged in deep and sincere soul searching, wracked with self-doubt and critical introspection, similarly experiencing radical, paradigmatic change in their methodologies and politics? Perhaps such introspection isn't fair or necessary. To be sure, many decent academics and researchers internationally have for decades rallied and railed against historical and contemporary injustices and have documented the role of education, PE and sport in the reproduction of social inequalities and other injustices such as racism, sexism, social class bias and ability elitism. Certainly some progress has been made in addressing these things. As a result, culturally, education, Physical Education and sport, both in and outside schools, have become far better, kinder, nicer, places for (most) children and young people to be, whether as spectators or participants.

Notwithstanding progress of this kind, fundamental inequalities and injustices prevail in education, PE, health and sport, as in wider society, irrespective of whether participation rates, representation in top level sport, longevity and health, or distributions of symbolic status and value, is our measure of success. And it is the 'left behind', labouring and impoverished middle classes that new Right politics claims now to best champion, who are more likely 'to fail' or be under represented in all of these things.

Against this backdrop, and as means of promoting some further reflection on these matters, we want to argue two things. First, that although the achievements of education and Physical Education, health and sport research communities in addressing equality and inclusion issues are many, varied and to be applauded, they are incomplete and have come at a cost. Educational research has helped make education, PE and sport, maybe even some aspects of wider society, better places for more people to be, socially and economically, and those achievements owe something to liberal democracy and the endeavours of its mostly wellintentioned 'liberal elite' in academia and the media (Freedland, 2016). Now is certainly not 
the time to denigrate those achievements, or seek to destabilize or, worse still, disestablish research communities which have, over very many decades, pursued agendas seeking to improve the lot of people in society and schools. There are plenty within and outwith our professions willing to do that for us, not least the voices of the old and new political right (Glaser, 2016). Now more than ever we need to counter the deeply regressive, conservative tendencies that threaten civil rights and liberties that many have fought for over many decades, and challenge the avalanche of half-truths and 'alternative facts' that rationalize and endorse those tendencies.

But somewhat reluctantly it has also to be acknowledged that the successes of research in education, PE, health and sport pedagogy of recent decades have come at a cost. Its tendency (our own included) to focus essentially on the cultural relations and politics of PE, health and sport (its xenophobia, racism, elitism, sexism, and other brutalities etc.,) has been at the expense of attention to those base, structural conditions and inequalities upon which social and cultural injustices and improprieties depend for their very existence. There has been a plethora of research literature internationally on the former in education, the sociology of physical education, health and sport; though it is still more difficult to cite material on say, ageism, homophobia, sexuality and transgender issues (of course with exceptions, such as, Griffin \& Genasci, 1990; Squires \& Sparkes, 1996; Cauldwell, 2006; Larsson, H., Quennerstedt, M., \& Öhman, M, 2014; Perez-Samaniego, Fuentes-Miguel, Pereira-Garcia \& Devis-Devis, 2016; lisahunter, forthcoming). To be sure, there is work to be done in the cultural politics of education, PE, health and sport. But it is even more difficult to identify research addressing say, the distribution of resources (not just symbolic, but material, physical, financial and temporal) in PEHS and how these underpin inequalities and injustices in society and schools. Rigorous research addressing questions of this kind is still rare (though again with exceptions, notably in the fields of sociology of sport and leisure, e.g., Rowe, 2014; Collins, 2014; Collins and Buller, 2003). In particular, we lack empirical data and accompanying theoretical analyses of the distribution of resources between areas/regions within nation states, between school communities/authorities and schools of different types, between male and female PE staff, male and female pupils, those deemed 'able' and 'less able', between black and white, or to particular sports and activities within the PE, health or sport curriculum. We lack description and analyses as to: who it is that determines and distributes these resources and by what principles; where lies the source of authority, power and control to determine these things, for example in England, whether as in newly privatised 
academies or traditionally governed school establishments (DCSF/DCMS, 2009; Evans and Davies, 2014, 2015; Macdonald, 2014; Powell, 2015). This list is not exhaustive but these and many other pressing issues (see below) are yet to be addressed. Failure to do so has consequences not only for the ability of lay and professional populations (pupils, parents, teachers, coaches, politicians) to address inequalities and broach social justice issues, but also for how educational research is perceived as having value in addressing inequality and fundamental human needs.

\section{Reflection}

What is it that stops us asking questions of this kind? The reasons are both exogenous and endogenous - that is to say, they are to be found both outwith and inside our professional practices. As to the former, there are very disturbing systemic pressures, born of neo liberalism and its manufactured austerities threatening the wellbeing of those very disciplines and research communities (the social sciences and humanities in particular) that are likely to be asking searching, sometimes difficult, questions of convention, extant social hierarchies and enduring injustices in education and beyond. Symptomatically:

On June 8 [2015], all presidents of national universities (in Japan) received a notice from the education minister telling them to either abolish their undergraduate departments and graduate schools devoted to the humanities and social sciences or shift their curricula to fields with greater utilitarian values.

The bad tradition of evaluating academic learning and sciences in terms of their utility, with private-sector enterprises meddling in higher education, is still alive in Japan. (Takamitsu, 2015)

This illustrates global tendencies, also evident in the UK, Europe, USA, some parts of Australasia, as they are in Japan that induce very many in our professions to feel threatened and vulnerable as to the normalisation of the necessity that they provide clear (quantifiable) evidence of their economic/financial value and virtue in Higher Education (HE) (meeting their unit costs and 'paying their way'). Regardless of any other contribution they might be making to scholarship or understanding of social processes and moral codes, the putative primacy of the needs of the economy in educational policy and planning has led to abject acquiescence of HE governance to economism and managerialism and their supporting surveillance and assessment systems over the last 40 years. Further erosion of the social 
sciences and humanities (and within them of sociology and critical pedagogy in particular) may be more than likely and could well presage fewer and fewer spaces for programmes of research and study that address social justice issues. The demise of the social sciences (or if not that, then their reductive realignment to management issues that better represent HE's instrumental purposes) of course has serious implications for research building capacity and processes of knowledge production addressing issues of inclusion and equity in society and schools. At the same time, it must be said there are very many good and decent people working in other disciplines, such as the bio and health sciences, who are concerned with issues of social justice (with whom border crossings must be made). But one cannot have too high a hope and expectation that either they or their students, though expertly steeped in, say, knowledge of what makes pupils and athletes tick psychologically, or how their muscle fibers work, will be equally well equipped or inclined to address how those muscled bodies are to act ethically, in school and wider contexts that are both equitable and inclusive, given our usual subject insularities.

Others have written at length about the contemporary malaise of neo-liberal managerialism (e.g., Shore, 2010; Sparkes, 2013; Macdonald, Hay and Williams 2008) and its attendant deleterious effects on individuals within HE and schools and their arguments need not be reiterated here. Instead, we now refer briefly to the endogenous factors that may have inhibited our asking critical questions of a kind that could help us better address the contemporary socio-political malaise. These are given more detailed attention in Evans and Davies $(2014,2015)$.

\section{The limitations within}

Elsewhere we have argued that the majority of research in the sociology of education and physical education over the last forty years has emanated from what Blackmore (2006) calls the politics of identity, as distinct from the politics of opportunity or political economy of education (Evans and Davies, 2014, 2015). The politics of identity is primarily (but of course not solely) concerned with the social re-production of class and cultural interests through the discursive production of identity and subjectivity. The latter seek to address issues relating more to the intersections of politics and economics, focusing on procedural justice, forms of governance and, particularly decision-making processes relating to recognition, selection and distribution of resources (physical, economic and human), including dispositions called 'ability', within and by families, schools and governments. Attention to the politics of 
identity has undoubtedly heightened sensitivity to and respect for 'difference' and the ways in which children's identities are brought into being, are 'performed' and either valued or abjectified in the process in the multiple practices of schools and their transactions with those of families and others outside them. However, the politics of opportunity and political economy of $\mathrm{PE}$, health and sport has taken something of a back seat during this time. All too rarely has research in PE, health and sport (ours included) reported on issues of distribution (as mentioned above), or of governance, or how individuals and/or populations gain access to particular schools of different sorts, or the educational opportunities within and between them, or the differential distributions of human and economic resource to PE, health and sport across and within educational sectors. Yet, given the socio-political world we now inhabit, now more than ever, attention to both the political economy of education and cultural politics is required if the effects of new Right politics and conservative populism on PE, teachers, pupils, parents, families and others with vested educational interests are to be systematically explored and better understood (see Lynch and Lodge, 2002). Again we emphasise, these are dangerous times for social democracy in the UK, across Europe, Australasia, the USA and elsewhere. In economic recession people and populations (especially if fuelled by callous self-serving insensitivities) become less forgiving, less likely to erode or concede unhelpful boundaries of territory and thought; it becomes easier and convenient to scapegoat others, usually the vulnerable or those seen as 'different' to ourselves and to draw on and consolidate stereotypes and cruel categorisations when apportioning blame for economic and political failings. In these circumstances, research on difference, on educational transactions and identity remains vital.

But at the same time educational (and other) structures do change and matter greatly (see Ball, 2012; Rizvi and Lingard, 2010). Across the western world, new privatised relations of governance and control are emerging between private enterprise, governments and their various 'consumers'. Hence research is also required on the restructuring of education provision within and between the multiple agencies now involved in new and emerging relations of schooling in the UK as elsewhere (see, Arreman, and Holm, 2011; Macdonald, 2014; Pope, 2014). Again we emphasise that, sense needs to be made of the new diversity of provision emerging in education and PE, sport and health in the UK and elsewhere. Indeed, we share Ball's (2011) view that in an increasingly polyvocal, polycentric, decentralised, performative, privatised education market, we do need to ask, with real urgency, where does power and control now lie? (2) In a period of turbulent socio-economic change, when polices 
are emerging to address 'economic recession', active and effective responses to them do need to be well informed and underpinned by existing and on-going research. However, it is also apparent that, in current, fast changing circumstances, getting well informed is, as Ball attests, increasingly difficult in relation to education policy because as the state system is 'disarticulated', new players get involved and new methods of practice are introduced. The problem of knowing what is happening (in and around schools, PE, health and sport) and where, is made increasingly difficult as private providers, with commercial sensibilities and headquarters in other countries, take over chunks or aspect of education (see Ball, 2012; Evans and Davies, 2015). Thus, our need to understand new national and global policy environments for education, which pose new questions, practical problems and ethical challenges for PE, health and sport activists and researchers, requires urgent attention. Only reinvigorated attention to the political economy of education and the politics of opportunity will, in our view, enable the PE research community and beyond to properly analyse the auspices of current socio-political changes and to see who has access to and who benefits from PE, health and sport education within differently regulated privatised educational provisions

Given the magnitude (and pace) of current socio-economic change one could, of course, be forgiven for feeling rather bemused, confused and somewhat removed from the flow of politics and nexus of governance and control of education. We might feel baffled as to where and how we might begin research (generating knowledge, understandings, 'truths') that will help ensure the future of an equitable and inclusive PE, health and sport as an educational enterprise, whether in HE, privatised schools or initial teacher education (ITE). If (as we've elsewhere suggested) we accept Ball's $(2011,1)$ observation that recent developments in society and education policy, which affect the forms and modalities of educational provision and organisation, have 'outrun the current purview of our research agenda and therefore we need to adapt and adjust what it is we consider as research and political problems in order to catch-up', then we should, indeed, follow his injunction to ask different questions and look in different places for answers to them (Evans and Davies, 2014). However, we might need some new skills and sensibilities if we are going to address them successfully. Not least, in doing so we might need to make new associations and draw upon a greater range of social theory, including forms of business and financial analysis or to put it another way, we must 'follow the money' in uncovering points of control and influence in education. While we address these concerns, we take as axiomatic that research monitoring the effects of socio- 
economic changes on the cultural politics of education and PEHS will continue as vital endeavour.

Accepting this may necessitate making new international friendships and networks to embark on research that presages serious critical introspection (through publications, conference attendance and engagements with media and key policy makers) on the merits of existing and historical practices within education, the sociology of physical education, health sport. Such activity should simultaneously facilitate empirical investigation inspired by both cultural politics and a political economy of PE, health and sport, that better engage with the structural conditions, material experiences and personal interests of those populations that are (or feel) undervalued, misrepresented, or misrecognized in education policy, practice and educational research. The social sciences should not and cannot do this alone. Understanding social inequalities could benefit from engagements not just with concepts, methods and ideas within and between perspectives within the social sciences and humanities, but also with the knowledge/s of other relevant sport and health disciplines and of the communities they each serve (Evans, 2014; Kellie, 2009; Kalitzkus \& Twohig, 2006, Lawson, 2016). Again we emphasise, there is no one or single way to research, teach or innovate in directions that contest injustices of class and cultural inequalities and foster 'progressive' social change. Engaging with the core concepts that emerge from and define our disciplinary cultures and the perspectives, methodologies of other perspectives and disciplinary interests (especially where, when, and as, they bear on issues of social justice) is not 'sell out'. It is simply to acknowledge that 'border crossings', if approached in principled manner involving sharing ideas, concepts and practices between researchers, researched and others with vested interests in the outcomes and implications of what we say and do, is now more than ever what is needed if we are to better address persistent cultural hierarchies, structural inequalities and power relations, and to better understand the role and importance of research communities in both shaping and contesting these things (Evans, 2014; Lawson, 2016).

\section{Conclusion}

None of this represents appeasement of populism in educational research. It simply marks an appeal to return to issues of procedural justice, not at the expense of identity politics but as sister to it in the quest for social justice and equity, in and outside schools (Evans and Davies, 2014, 2015). At its very best research should help illuminate and challenge corrosive and 
reductive elements of policies and governance that put at risk the democratic nation state. It should intentionally unsettle and disturb polices, policy makers and other professionals in government, Higher Education and schools in the process, while offering guidance on renewal, social progress and growth. Populism and privatisation presage a new landscape, a new future perhaps, both for practitioners of physical education, health, sport and research. Critics (from the old and new political Right) will, of course, continue to accuse the social sciences and humanities of being too abstract, too theoretical, too far removed from the interests of practitioners and irrelevant to the task of addressing inequalities and improving the quality of education in schools. These claims are unfounded and, to the contrary, emphasise the place and importance of theory in research and the place of sociology and critical pedagogy in the wider educational practices of HE and schools (see Ball, 1994; Blunkett, 2008; Evans and Davies, 2002). Indeed, it might be said that if educational researchers have become too esoteric, too far removed from the concerns of teachers and disaffected populations, then they hardly are themselves to blame. No researcher in Higher Education in the UK and many elsewhere, in recent years will have escaped the influence of their Higher Education funding council's assessment procedures, which determine the level of research funding to be distributed to $\mathrm{HE}$ in good part on the basis of an assessment of their published research journal outputs (and demonstrable 'impact'). In the UK certainly, we have slipped dangerously towards a situation where, if the research findings are not published in journals considered 'scholarly', 'international' and 'high impact', they are not considered worthy of publishing at all, so that, in some senses, the more abstract the research, the better it is deemed to be. Educational researchers can hardly be blamed for this tendency, nor would many criticise the merits of this kind of work in education, PE, health and sport. They would, however, baulk at the notion that there is only one worthwhile way of doing research and one worthwhile way of disseminating findings, as would appear to be at the root of current thinking in some quarters of Higher Education these days. There is no logic to the claim that research in or on education and PEHS should be geared straightforwardly to fulfilling purely instrumental ends or to informing practitioners how its findings should be translated into pedagogical action in schools. Perhaps these critiques are simply expressions of a consumer culture (including governments and docile HE systems that define us all as merely consumers of their policy products) that increasingly define only the immediately relevant and consumable as useful and really worthwhile, while anything of more enduring quality is deemed inherently worthless or fundamentally flawed. Or, alternatively, they may be expression of a postmodern (post-truth, new Right) epistemological tendency toward 
believing that, as all knowledge is inevitably transient and ephemeral, then no form of research, educational or otherwise, is worth doing at all (Smith, 1998; Constas 1996). Neither are views to which we would subscribe as both absolve politicians (and practitioners) from the awkward business of questioning cultures and structures (Evans and Davies, 2002).

Sadly, in Government and increasingly in HE policy discourse, very little is now deemed worth knowing or doing unless it is easily measurable, quantifiable, or amenable to an evidence base; ruling out risk-taking inspirational theory and practice and most that seek to privilege enjoyment, satisfaction, empowerment, equity, dignity, responsibility, independence. While no educational researcher in PEHS would baulk at the claim that, where possible and desirable, actions should be grounded in empirical research and inquiry as well as in other forms of knowledge (for example, moral judgement) few, we suspect, would want to go on to suggest that we treat complex social and educational problems relating to learning and teaching, or equity and inclusion as if they were solvable simply by throwing quick-fix data at them. To do so would be to engage in the kind of instrumental empiricism that is as disreputable in research terms as it is unlikely to lead to improvements in education and the achievement of worthwhile educational goals. There is a world of difference between registering the conditions that ferment populism and engaging in populist (quick fit, fact light, sexy, relevant but ephemeral) research. We know that if research is to be of enduring value it has to be theoretically led, cumulative and comprehensive in focus and, perhaps above all else, critically reflexive not only in relation to its own actions and the problems that either it wants, or others want it to explore, but also to what problems are worth addressing, what research is for, who sets agendas and the interests that it serves. We need independence and risk taking in research environments, just as we do in teaching, classrooms and schools. If PEHS research in HE and schools is to be seen as credible means of addressing current socioeconomic change including the worst excesses of new Right populism and its effects on equity and inclusion in society and schools, then it will be because its practices are based on research expertise and theoretical bodies of knowledge that are attuned to structural inequalities and the cultural interests of its target communities (e.g., Lawson and van Veen, 2016). In current political climes, we erode these elements of our practices at our peril, if social democracy is what we want to preserve. 
1

2

3

4

5

6

7

8

9

10

11

12

13

14

15

16

17

18

19

20

21

22

23

24

25

26

27

28

29

30

31

32

33

34

35

36

37

38

39

40

41

42

43

44

45

46

47

48

49

50

51

52

53

54

55

56

57

58

59

60

11
13
4
5
5
17
18
19
90
21
22
23
24
25
26
27
28
29
30
31
32
33
34
35

\section{Acknowledgement}

We are extremely grateful to Lisette Burrows, Jan Wright and Michael Gard for their comments on an earlier draft of this paper. \\ Page 13 of $19 \quad$ Sport, Education and Society}

(2) (1)

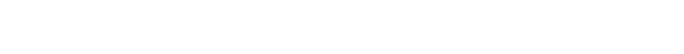


Notes

1. Pankaj Mishra draws upon the term 'ressentiment' to refer to 'an existential resentment of other people's being, caused by an intense mix of envy and sense of humiliation and powerlessness, ressentiment, as it lingers and deepens poisons civil society and undermines political liberty, and is presently making for a global turn to authoritarianism and toxic forms of chauvinism' (Mishra, 2017, p.14).

2. The views expressed in this and the concluding section of the paper, were first outlined in Evans and Davies, 2002, 2014 and 2015. 


\section{Bibliography}

Arreman, I.E. \& Holm A.S. (2011). Privatisation of public education? The emergence of independent upper secondary schools in Sweden. Journal of Education Policy 26 (2), 225243.

Ball, S. J. (2011). A New research agenda for educational leadership and policy. Management in Education, 25(2), 50-52.

Ball, S. J. (2012). Global Education Inc. New Policy Networks and the Neo-Liberal Imaginary. London: Routledge.

Ball, S. (1994). Intellectuals or Technicians? The Urgent Role of Theory in Educational Studies: Annual Address to the Standing Conference for Studies of Education, RSA, November 4, 1994.

Bellow, W. (2014). How Liberal Democracy Promotes Inequality, Foreign Policy in Focus http://fpif.org/liberal-democracy-promotes-inequality/ accessed 13/2/2017, no page number)

Blackmore, J. (2006). Deconstructing Diversity Discourses in the Field of Educational Management, Educational Management Administration \& Leadership, 34(2), 181

Blunkett, D. (2000). Influence or Irrelevance: can social science improve government? Research Intelligence, BERA Newsletter, 71, March, pp.12-21.

Caudwell, J. (Ed) (2006). Sport, sexualities and queer/theory. Abingdon, Oxon: Routledge

Collins, M. F. (2014). Sport and Social Exclusion, London: Routledge.

Collins, M. F. \& Buller, J.R. (2003). Social exclusion from h igh-performance sport are all talented young sports people being given an equal opportunity of reaching the Olympic podium? Journal of Sport \& Social Issues 27(4), 420-442. 
Constas, M.A. (1996). The Changing Nature of Educational Research and a Critique of Postmodernism, in Educational Researcher, 27(2), 26-33

DCSF/DCMS. (2009). The impact of the commercial world on children's wellbeing: Report of an independent assessment for the Department for Children, Schools and Families and the Department for Culture, Media and Sport, Nottingham: DCSF.

Evans, J. (2014). Ideational border crossings: rethinking the politics of knowledge within and across disciplines, Discourse: Studies in the Cultural Politics of Education, 35(1), 45-61,

Evans, J. \& Davies, B. (2002). "Theoretical Background", in The Sociology of Sport and Physical Education, (Ed) Laker, A., London and New York: Routledge/Falmer, pp.1-15.

Evans, J. \& Davies, B. (2014). Physical Education PLC: neoliberalism, curriculum and governance. New directions for PESP research, Sport, Education and Society, 19(7), 869-884.

Evans, J. \& Davies, B. (2015). Neoliberal freedoms, privatisation and the future of physical education, Sport, Education and Society, 20(1), 10-27

Freedland, J. (2016). Don't be fooled by these attacks on the metropolitan liberal elite, The Guardian on line, https://www.theguardian.com/commentisfree/2016/dec/23/dishonestattacks-metropolitan-liberal-elite, accessed 16/2/2017)

Glaser, E. (2016). In defense of the metropolitan elite, The New Statesman on line, http://www.newstatesman.com/politics/staggers/2016/10/defence-metropolitan-elite, (accessed 13/2/2016).

Griffin, P \& Genasci, J. (1990). Addressing homophobia in physical education: responsibilities for teachers and researchers, in Messner M. A. and Sabo, D.F (eds) Sport, Men and the Gender Order, Leeds: Human Kinetics 
Kalitzkus, V. \& Twohig, P.L. (Eds.) (2006). Bordering biomedicine. Amsterdam/New York: Rodopi.

Keate, G. (2012). Over half of secondary schools now Academies, Politics.Co.Uk http://www.politics.co.uk/news/2012/09/07/over-half-of-secondary-schools-now-academies

Kellie, J. (2009). What can interdisciplinarity offer to policy problems? Understanding the public policy of obesity, European Political Science, 8 (1), 47-56.

Larsson, H., Quennerstedt, M., \& Öhman, M. (2014). Heterotopias in physical education- towards a queer pedagogy? Gender \& Education. 26(2), 135-50

Lawson, H. A. (2016). Stewarding the discipline with cross-boundary leadership. Quest, 68(2), 91-115.

Lawson, H. A., \& van Veen, D. (2016). Developing community schools, community learning centers, extended service schools, and multi-service schools: International exemplars for research, policy and practice. The Hague, NL: Springer International.

lisahunter (forthcoming). What a queer space is HPE, or is it yet? Queer theory, sexualities and pedagogy, Sport, Education and Society, (in press).

Lynch, K \& Lodge, A. (2002). Equality and Power in Schools, London: Routledge

Macdonald, D. (2014). Is global neoliberalism shaping the future of physical education, Physical Education and Sport pedagogy, 19(5), 494-500.

Macdonald, D., Hay, P., \& Williams, B. (2008). Should you buy? Neo-liberalism, neo-HPE, and your neo-job. New Zealand Physical Educator, 41, 6-13.

Mishra, P. (2017). Age of Anger: A history of the Present, London: Macmillan.

Mol, M. J. (2007).Outsourcing: Design, process, and performance, Cambridge: Cambridge 
University Press.

Montague, A. (2012). Using Physical Education and Sport to Raise School Standards, Better Evidence-based Education, The University of York: Institute for Effective Education.

Perez-Samaniego,V., Fuentos-Miguel, J., Pereira-Garcia, S., \& Devis-Devis, J. (2016). Abjection and Alterity in the imagining of transgender in physical education and sport: a pedagogical approach in higher education, Sport, Education and Society, 21(7), 985-1003.

Pope, C. (2014). The Jagged Edge and the Changing Shape of Health and Physical Education in Aotearoa New Zealand, Physical Education and Sport Pedagogy, 19(5), 500-512

Powell, D. (2015). Assembling the privatisation of physical education and the 'inexpert' teacher, Sport, Education and Society, 20(1), 73-89.

Rowe, N. (2014). Sporting capital: a theoretical and empirical analysis of sport participation determinants and its application to sports development policy and practice, International Journal of Sport Policy and Politics, 7(1), 43-61.

Rizvi, F. \& Lingard, B. (2010). Globalizing Education Policy, London: Routledge.

Smith, J. K. (1998). Learning to Live with Relativism, in Hodkinson, P. (Ed) "The Nature of Educational Research: Realism, Relativism or Post-Modernism?", Manchester: The Manchester Metropolitan University.

Shore, C. (2010). Beyond the multiversity: neoliberalism and the rise of the schizophrenic university, Social Anthropology/Anthropologie Sociale, 18(1), 15-29.

Sparkes, A. C. (2013). Qualitative research in sport, exercise and health in the era of neoliberalism, audit and New Public Management: understanding the conditions for the (im)possibilities of a new paradigm dialogue, Qualitative Research in Sport, Exercise and Health, 5(3), 440-459. 
Squires, S. L \& Sparkes, A.C. (1996). Circles of Silence: Sexual Identity in Physical Education and Sport, in Sport, Education and Society 1, (1), 77-103 (accessed, 6/9/12).

Takamitsu, S. (2015). Humanities under attack, The Japan Times, on line, http://www.japantimes.co.jp/opinion/2015/08/23/commentary/japan-commentary/humanitiesattack/\#.WJopy8tvjIU (accessed 13/2/2017).

Williams, B. J., Hay. P. J., Macdonald, D. (2011). The outsourcing of health, sport and physical educational work: a state of play, Physical Education \& Sport Pedagogy, 16(4), 399415).

Williams, B.J \& Macdonald, D. (2015). Explaining outsourcing in health, sport and physical education, Sport, Education and Society, 20(1), 57-73.

Yates, W.B. (1919). The Second Coming, http://www.potw.org/archive/potw351.html (accessed 13/2/2017) 